Jurnal Informatika dan Rekayasa Perangkat Lunak (JATIKA)
Vol. 1, No. 1, June 2020, 120-126

\title{
PERANCANGAN APLIKASI PENERIMAAN PESERTA DIDIK BARU (PPDB) PADA SMK YADITAMA SIDOMULYO BERBASIS WEB
}

\author{
VELIS DWI CAHYANI ${ }^{1}$ \\ SIInformatika ${ }^{1}$ (Universitas Teknokrat Indonesia) \\ velisdqicahyani@gmail.com ${ }^{1}$
}

Received: (Juni 2020)Accepted: (Juni 2020) Published: (Juni 2020)

\begin{abstract}
The process of accepting new students at SMK Yaditama Sidomulyo still uses the registration form and only uses a written test or NUN (National Examination Score) especially at SMK Yaditama Sidomulyo, in registration students must come directly to school, then fill out the registration form manually and then submit to the committee the following requirements requirements and make administrative payments manually because there are still too few ATMs, then the committee gives a card for the acceptance test. With a system that runs student data values that must be checked to determine whether students are accepted or not too much and the committee officer is only a little so it takes a long time, because the assessment procedures that apply are fast and precise. The system development method used is Extreme Programming and system design using UML (Unified Modeling Language). By using interview data collection methods, observation, and documentation regarding the admission of new students. This research resulted in an Application for Acceptance of New Students at SMK Yaditama Sidomulyo online. This system will be built using the SAW method, which is to find the weighted sum of the performance ratings on each alternative for all attributes in the student admission process.
\end{abstract}

Keywords: Applications, Admissions, Students, Extrme Programming, ISO 9126.

\begin{abstract}
Abstrak
Proses penerimaan siswa baru pada SMK Yaditama Sidomulyo masih menggunakan formulir pendaftaran dan hanya menggunakan tes tertulis atau NUN (Nilai Ujian Nasional) khususnya di SMK Yaditama Sidomulyo, dalam pendaftaran siswa harus datang langsung kesekolah, kemudian mengisi formulir pendaftaran secara manual lalu menyerahkan kepada panitia berikut syarat-syarat dan melakukan pembayaran administrasi secara manual dikarenakan masih terlalu jarang adanya ATM, selanjutnya panitia memberikan kartu untuk test ujian penerimaan. Dengan sistem yang berjalan data nilai siswa yang harus diperiksa untuk menentukan siswa yang diterima atau tidak terlalu banyak dan petugas panitia hanya sedikit sehingga membutuhkan waktu yang lama, karena prosedur penilaian yang berlaku yaitu dengan cepat dan tepat. Metode pengembangan sistem yang digunakan adalah Extreme Prrogramming dan perancangan sistem menggunakan UML (Unified Modeling Language). Dengan menggunkan metode pengumpulan data wawancara, observasi, dan dokumentasi mengenai penerimaan siswa baru. Penelitian ini menghasilkan suatu Aplikasi Penerimaan Peserta Didik Baru Pada SMK Yaditama Sidomulyo secara online.Sistem ini akan dibangun menggunakan metode SAW yaitu untuk mencari penjumlahan terbobot dari rating kinerja pada setiap alternatif pada semua atribut dalam proses penerimaan siswa.

Kata Kunci: Aplikasi, Penerimaan, Peserta Didik, Extrme Programming, ISO 9126.
\end{abstract}

\section{To cite this article:}

Velis Dwi Cahyani. (2020). PERANCANGAN APLIKASI PENERIMAAN PESERTA DIDIK BARU (PPDB) PADA SMK YADITAMA SIDOMULYO BERBASIS WEB. Jurnal Informatika dan Rekayasa Perangkat Lunak, Vol(1), 120-126.

\section{PENDAHULUAN}

Teknologi Informasi adalah suatu teknologi yang digunakan untuk mengolah data, termasuk mendapatkan, menyusun, memproses, menyimpan untuk menghasilkan informasi yang berkualitas, akurat dan tepat waktu sehingga bisa digunakan untuk keperluan pribadi, bisnis, pendidikan, dan pemerintahan. Teknologi informasi salah satunya diterapkan dengan teknologi internet dan web yang mampu mendukung proses input dan output data secara cepat dan akurat, khususnya dalam pelaksanaan penerimaan siswa baru. Hasil penerapan 
teknologi ini akan mengurangi biaya dalam proses pendaftaran, meningkatkan mutu Sekolah, dan mempercepat proses pengelolaan data pendaftarannta. Tetapi pada kenyataannya, program penerimaan siswa baru disekolahsekolah yang dimulai dengan proses pendaftaran, penyeleksian dan pengumuman tersebut masih dilaksanakan dengan cara manual salah satunya telah diterapkan pada SMK Yaditama Sidomulyo (Patta, 2012).

SMK Yaditama Sidomulyo berdiri pada tanggal 17 Januari 1989, Yayasan Wiyata Mandala (YAWIMA) merupakan yayasan yang dibangun dengan tanah milik sendiri yang beralamat di Jl. Perintis Kemerdekaan No. 70 A Sidomulyo, Lampung Selatan. Berdasarkan wawancara dengan waka kesiswaan pendaftaran siswa baru setiap tahun sekitar 300 siswa atau lebih yang mendaftar dan siswa yang diterima sekitar 275 siswa. Terdapat 4 jurusan yaitu, Akuntansi dan Keuangan Lembaga, Otomatisasi dan Tata Kelola Perkantoran, Teknik Komputer dan Jaringan, dan Teknik dan Bisnis Sepeda Motor.

Proses penerimaan siswa baru pada SMK Yaditama Sidomulyo masih menggunakan formulir pendaftaran dan hanya menggunakan tes tertulis atau NUN (Nilai Ujian Nasional) khususnya di SMK Yaditama Sidomulyo, dalam pendaftaran siswa harus datang langsung kesekolah, kemudian mengisi formulir pendaftaran secara manual lalu menyerahkan kepada panitia berikut syarat-syarat dan melakukan pembayaran administrasi secara manual dikarenakan masih terlalu jarang adanya ATM, selanjutnya panitia memberikan kartu untuk test ujian penerimaan. Terdapat ujian yang dilakukan yaitu test tertulis berdasarkan hasil test tersebut maka akan dikumpulkan dan dihitung nilai secara manual sebagai pertimbangan panitia PSB dengan melihat nilai tertinggi dari setiap jurusan. Setelah dilakukan proses penentuan maka akan di rekap siswa yang diterima dan akan diumumkan melalui papan pengumuman sekolah. Pada proses yang berjalan dalam mengambil keputusan siswa mana yang diterima atau tidak, harus memperhatikan nilai siswa satu persatu setiap jurusan sehingga membutuhkan waktu yang lama, dan sulit memutuskan jika terjadi kesamaan nilai siswa. Dengan sistem yang berjalan data nilai siswa yang harus diperiksa untuk menentukan siswa yang diterima atau tidak terlalu banyak dan petugas panitia hanya sedikit sehingga membutuhkan waktu yang lama, karena prosedur penilaian yang berlaku yaitu dengan cepat dan tepat.

Sistem informasi penerimaan siswa baru sebelumnya telah dilakukan penelitian oleh Putu (2016) dan Didik Pambudi (2012), meneliti tentang Pengembangan Sistem Pendukung Keputusan Penerimaan Siswa Baru Hasil dari penelitian ini yaitu berupa suatu aplikasi sitem pendukung keputusan penerimaan siswa baru di SMA. Ningtyas (2018) dan Mulyani (2017), meneliti tentang Sistem Informasi Penerimaan Peserta Didik Baru. Hasil penelitian ini adalah membuat sebuah sistem informasi penerimaan peserta didik baru dengan maksud mempermudah calon peserta didik dan sekolah dalam proses penerimaan peserta didik baru. Dan diteli oleh Siren (2019), meneliti tentang Evaluasi Kualitas Perangkat Lunak Menggunakan ISO/IEC 9126-4 Quality In Use (Studi Kasus : FILKOM Apps). Terdapat kendala yaitu pada E-learning Fakultas Ilmu Komputer Universitas Bandar Lampung belum memenuhi level yang dibutuhkan dari tiga karakteristik yaitu effectivity, productivity, safety dan hanya memenuhi level yang dibutuhkan dari satisfaction. Menggunakan metode pengujian ISO/IEC 9126-4. Hasil evaluasi mendapatkan penilaian yang baik, karena semua sesuai dengan rentang yang telah ditetapkan ISO/IEC 9126-4 Quality In Use.

\section{TELAAH PUSTAKA \\ PERANCANGAN}

Perancangan adalah penggambaran, perencanaan, dan pembuatan sketsa atau pengaturan dari beberapa elemen yang terpisah kedalam suatu kesatuan yang utuh dan berfungsi. Dengan demikian pengertian rancang bangun merupakan kegiatan menerjemahkan hasil analisa ke dalam bentuk paket perangkat lunak kemudian menciptakan sistem tersebut atau memperbaiki sistem yang sudah ada (Pressman, 2015).

\section{APLIKASI}

Aplikasi merupakan program yang dikembangkan untuk memenuhi kebutuhan pengguna dalam menjalankan pekerjaan tertentu. Perangkat lunak aplikasi dibedakan menjadi beberapa macam berdasarkan kegunaannya (Maryono, 2016).

\section{PENERIMAAN SISWA BARU}

Kegiatan rutin dari sekolah untuk melakukan penerimaan calon murid yang memenuhi syarat tertentu untuk memperoleh pendidikan pada bentuk satuan pendidikan dan mengikuti suatu jenjang pendidikan yang lebih tinggi (Palilingan, 2014). 


\section{METODE}

\section{Kerangka Penelitian}

Kerangka penelitian adalah suatu rancangan alur sebuah penelitan yang terstruktur disampaikan melalui gambar yang berurutan sesuai dengan tahapan apa saja yang akan dilakukan dalam melakukan suatu penelitian.

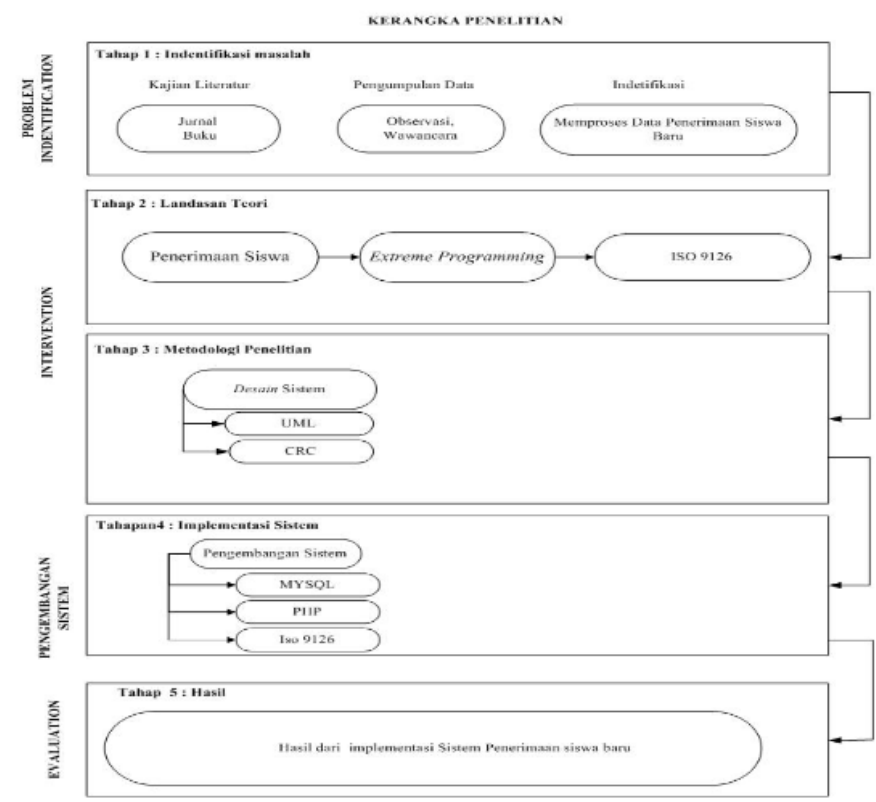

Gambar 1. Kerangka Penelitian

\section{Teknik Pengumpulan Data}

Tahapan ini melakukan teknik pengumpulan data yang dilakukan penulis dalam penelitian ini adalah sebagai berikut :

1. Observasi Pengumpulan data melalui pengamatan secara langsung di SMK Yaditama Sidomulyo.

2. Wawancara Peneliti akan melakukan wawancara secara langsung dengan guru terkait dengan proses penginputan nilai dari wawancara tersebut diperoleh informasi tentang permasalahan sehingga mendukung untuk mencari jalan keluar dari permasalahan yang ada.

3. Dokumentasi yang digunakan pada penelitian ini adalah dokumentasi dari kegiatan observasi serta proses wawancara yang dilakukan oleh peneliti.

4. Studi Literatur dilakukan kajian literatur dari beberapa jurnal, E-book, buku-buku referensi dan sumber sumber lain yang berkaitan dan dapat mendukung dalam pembuatan penelitian ini.

\section{Analisis Kebutuhan Sistem}

Penelitian ini dilakukan dengan menggunakan alat alat baik berupa perangkat keras maupun perangkat lunak. Kebutuhan fungsional yang dapat dilakukan pada sistem ini adalah sebagai berikut:

1. Siswa
a) Siswa dapat melakukan registrasi
b) Siswa dapat melakukan login
c) Siswa dapat mengisi biodata dan upload persyaratan pendaftaran
d) Siswa melihat informasi pendaftaran
e) Siswa dapat melihat hasil pengumuman

2. Admin

a) Admin dapat melakukan login

b) Admin dapat melakukan validasi pendaftaran 
c) Admin dapat mencetak laporan pendaftaran dan penerimaan

d) Admin dapat mengelola nilai hasil ujian

\section{Kepala Sekolah}

a) Kepala Sekolah dapat melakukan login

b) Kepala Sekolah dapat melihat laporan pendaftaran

c) Kepala Sekolah dapat melihat laporan penerimaan

\section{HASIL DAN PEMBAHASAN}

\section{Desain Sistem}

Desain sistem merupakan tahap yang menentukan proses dan data yang diperlukan oleh sistem baru. Desain sistem ini merupakan gambaran secara menyeluruh mengenai urutan pengolahan data dari persiapan desain sistem sampai menghasilkan laporan yang dibutuhkan.

\section{Usecase Diagram}

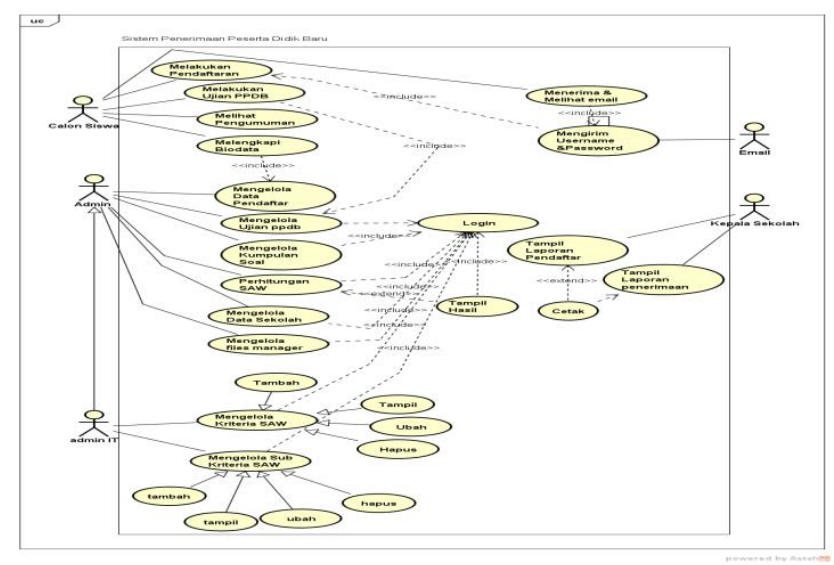

Gambar 2. Usecase Diagram

\section{Menu Utama}

Menu utama adalah tampilan yang menampilkan tampilan awal program. Pada tampilan ini terdapat button daftar untuk melakukan pendaftaran, dan button masuk untuk masuk kedalam sistem setelah melakukan registrasi. Adapun tampilannya sebagai berikut:

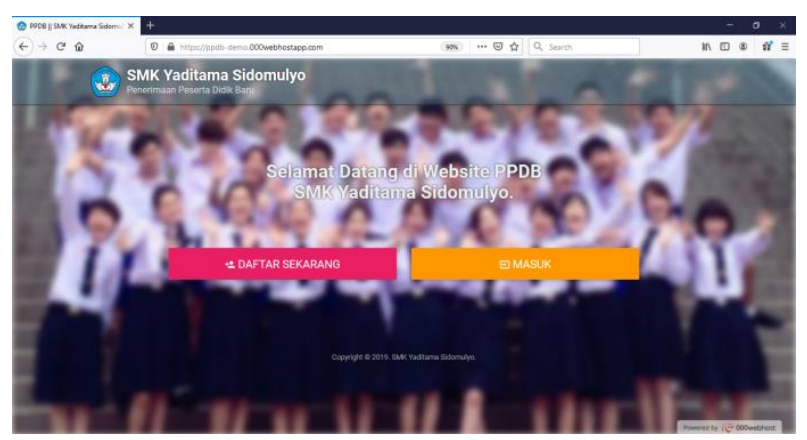

Gambar 3. Menu Utama

\section{Menu Jurusan}

Menu jurusan adalah menu untuk mengelola data jurusan sekolah. Adapun tampilan data jurusan sekolah sebagai berikut: 


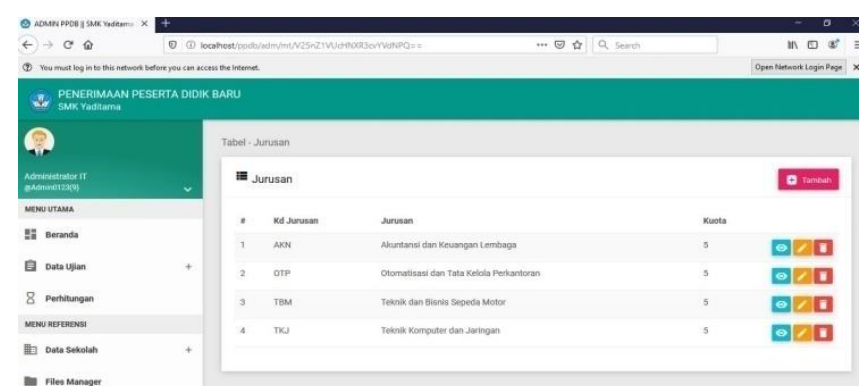

Gambar 4. Menu Jurusan Sekolah

\section{Menu Tahun Pelajaran}

Menu tahun pelajaran adalah menu untuk mengelola data tahun. Adapun tampilan data tahun pelajaran sebagai berikut:

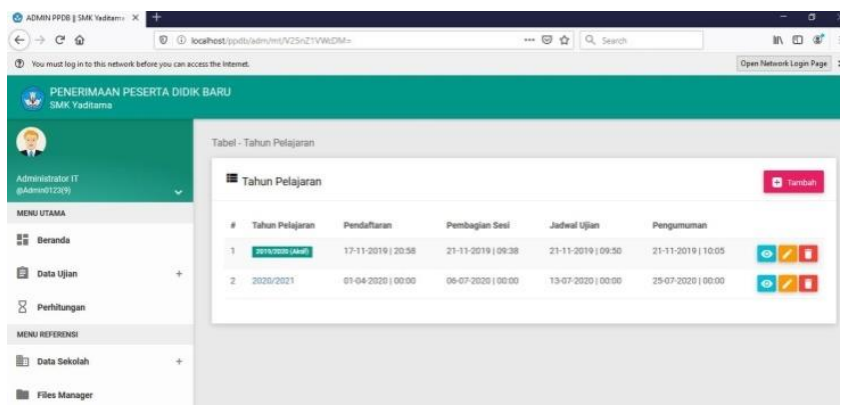

\section{Gambar 5. Menu Tahun Pelajaran}

\section{Menu Kriteria}

Menu kriteria adalah menu untuk mengelola data kriteria perhitungan. Adapun tampilan data kriteria sebagai berikut:

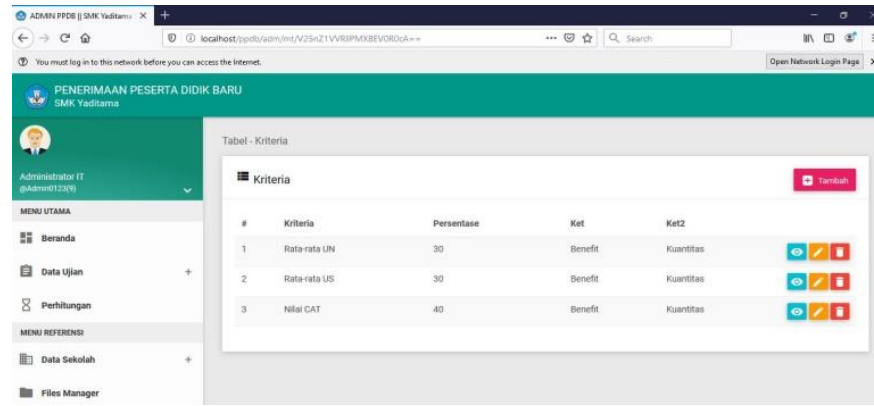

\section{Gambar 6. Menu Kriteria}

\section{Menu Sub Kriteria}

Menu sub kriteria adalah menu untuk mengelola data sub kriteria perhitungan. Adapun tampilan data sub kriteria sebagai berikut: 


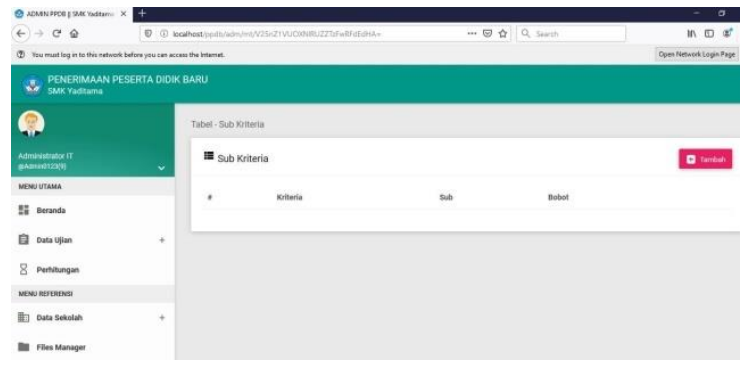

Gambar 7. Menu Sub Kriteria

\section{Pengujian Sistem}

Berikut hasil pengujian ISO 9126 secara keseluruhan pada aplikasi dapat dilihat pada table bawah ini:

Tabel 1. Hasil Keseluruhan Pengujian ISO 9126

\begin{tabular}{|c|c|c|c|c|}
\hline Aspek & SkorAktual & Skor Ideal & \% SkorAktual & Kriteria \\
\hline Functionality & 705 & 750 & 94,00 & SangatLayak \\
\hline Usability & 430 & 500 & 86,00 & Layak \\
\hline Efficiency & 181 & 200 & 90,50 & SangatLayak \\
\hline Total & 1316 & 1450 & 90,76 & SangatLayak \\
\hline
\end{tabular}

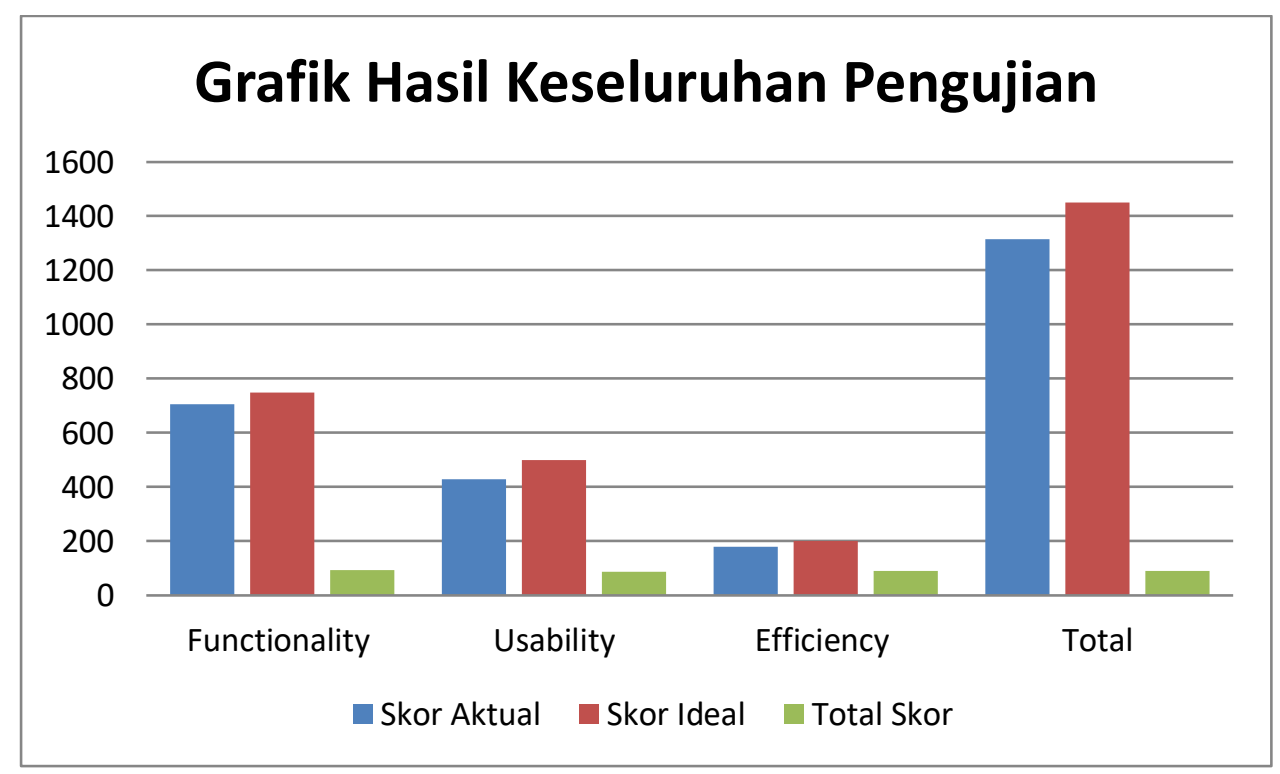

Gambar 8. Grafik Hasil Keseluruhan Pengujian

Berdasarkan hasil pengujian ISO 9126 yang telah dilakukan dengan melibatkan 10 Responden bahwa kesimpulan kualitas kelayakan perangkat lunak dengan skor $90.76 \%$ yang dihasilkan secara keseluruhan mempunyai skala "Sangat Layak" dan dinilai layak untuk diterapkan pada Sekolah, untuk penjabaran kuisioner terkait pengujian ISO 9126 yang telah dilakukan.

\section{SIMPULAN}

Pengembangan sistem penerimaan siswa baru untuk membantu proses seleksi siswa yang diterima dengan menggunakan metode SAW dalam bentukwebsite pada SMK Yaditama Sidomulyo dimulai dari metode 
pengumpulan data (wawancara, pengamatan, dokumentasi) menggunakan metode pengembangan extreme programmingsehingga dibuatlah rancangan system menggunakan UML yaitu dengan model perancangan Usecase, dan Class Diagram dan desain sistem inputan menggunakan PHP dan MySQL, dengan diterapkannya metode SAW dapat menghitung secara otomatis penerimaan siswa yang masuk ke masingmasing jurusan yang dipilih, dan yang akan mempermudah sekolah dalam melakukan penilaian dan menghasilkan laporan yang diinginkan oleh sekolah, dan hasil pengujian ISO 9126 yang telah dilakukan dengan melibatkan 10 Responden bahwa kesimpulan kualitas kelayakan perangkat lunak dengan skor $90.76 \%$.

\section{UCAPAN TERIMA KASIH}

Pada bagian ini, penulis menyampaikan ucapan terima kasihnya kepada sumber pendanaan atau bantuan yang diterima, dan pihak lain memainkan peran penting dalam melaksanakan studi Anda dan / atau menyiapkan naskah jika ada sebelum referensi.

\section{REFERENSI/DAFTAR PUSTAKA}

Asri Mulyani, dan Faisal Nurur Ramadhan. 2017. Rancang Bangun Sistem Informasi Penerimaan Santri Baru Di Sekolah Dasar Islam Terpadu Persis Tarogong Berbasis Web. Jurnal STT. 160-169.

Damayanti, Nirmalasari. 2019. Sistem Informasi Manajemen Penggajian dan Penilaian Kinerja Pegawai pada SMK Taman Siswa Lampung. Jurnal Teknologi Informasi dan Ilmu Komputer.

Megawaty, D. A. 2015. Penerimaan Layanan Keuangan Dalam Belanja Online Berdasarkan Tingkatan Generasi.

Fatha, H. A. 2012. Analisis dan Perancangan Sistem Informasi. Andi. Yogyakarta.

Ketut Rindjin. 2000. Penghantar Sistem Pendukung Keputusan. Gramedia. Jakarta

Maryono. 2016. Desain Sistem Pembelajaran. Refika. Jakarta

Ningtyas Dwi Arumet al. 2018. Sistem Informasi Penerimaan Peserta Didik Baru Pada Smp Ar-Ridha Jakarta. Jurnal TECHNO. 19-24

Palilingan. 2014.Analisis Sikap Kerja Penelitian. Alfa. Bandung

Patta, Abdul Rahim. 2012. Pengembangan Sistem Informasi Penerimaan Siswa Baru Berbais WEB dan SMS Gateway. Jurnal Teknologi. 1066-1077.

Putu Angga Septiana Putraet al. 2016. Pengembangan Sistem Pendukung Keputusan Penerimaan Siswa Baru Di Sma Negeri 1 Seririt Engan Metode SAWDan Metode AHP. Jurnal IDeaTech. Volume 5, Nomor 1, Januari 2016

Pressman, Roger S.2015. Rekayasa Perangkat Lunak: Pendekatan Praktisi (Buku Satu). Andi. Yogyakarta.

Siren Victor Axelius Kristiantoet al. 2019. Evaluasi Kualitas Perangkat Lunak Menggunakan ISO/IEC 9126-4 Quality In Use (Studi Kasus : FILKOM Apps). Jurnal Pengembangan Teknologi Informasi dan Ilmu Komputer. 1625-1632.

Suryono, R. R., Darwis, D., Gunawan, S. I. 2018. Audit Tata Kelola Teknologi Informasi Menggunakan Framework Cobit 5 (Studi Kasus: Balai Besar Perikanan Budidaya Laut Lampung). Jurnal Teknoinfo, 2018 